\title{
Prevalence of urinary incontinence among the elderly and relationship with physical and mental health indicators
}

Marciane Kessler' Luiz Augusto Facchini² Mariangela Uhlmann Soares' Bruno Pereira Nunes' Sandra Mattos França ${ }^{1}$ Elaine Thumél

\section{Abstract}

Objective: to verify the prevalence of urinary incontinence and its relationship with physical and mental health indicators in the elderly population of Bagé, Rio Grande do Sul, Brazil. Method: a cross-sectional population-based study was conducted in 2008 with 1,593 elderly persons. Poisson regression was used for crude and adjusted analysis between the outcomes and the independent variables. Results: the prevalence of urinary incontinence was $20.7 \%$, being $26.9 \%$ among women and $10.3 \%$ among men. The associated factors were female gender, age 70 to 74 and 75 years or over, yellow/brown/indigenous ethnicity/skin color and no schooling. The prevalence of functional disability, depression, cognitive deficit and very poor/poor self-perception of health was significantly higher in women with urinary incontinence. Among incontinent men, the same was observed with regard to functional disability and cognitive deficit. Conclusion: the occurrence of urinary incontinence in the elderly is frequent, especially in women, with a significant relationship with physical and mental health conditions in the elderly population. These results support the development of care strategies to prevent incontinence and minimize its health impacts.

\footnotetext{
Universidade Federal de Pelotas, Faculdade de Enfermagem, Programa de Pós-Graduação em Enfermagem. Pelotas, Rio Grande do Sul, Brasil.

2 Universidade Federal de Pelotas, Departamento de Medicina Social, Programa de Pós-Graduação em Epidemiologia e Programa de Pós-Graduação em Enfermagem. Pelotas, Rio Grande do Sul, Brasil.
}

\section{Keywords: Health of the} Elderly. Urinary Incontinence. Disabled Persons. Primary Health Care. Epidemiology. 


\section{INTRODUCTION}

While the physiological disorder of urinary incontinence (UI) is not inherent to the aging process, it tends to manifest itself more frequently with advancing age and is considered one of the main geriatric syndromes ${ }^{1-3}$. In this sense, the progressive increase in the absolute and relative number of elderly people due to increased life expectancy and population aging has led to an increase in the occurrence of $\mathrm{UI}^{1,4}$.

The International Continence Society defines UI as any involuntary leakage of urine ${ }^{5}$ and the condition is multifactorial in origin. Specialized literature shows that the factors associated with its occurrence are: the female gender and advanced age $^{6-8}$, non-Caucasian ethnicity ${ }^{9}$ and the lack of or low levels of schooling ${ }^{8-10}$. Studies have shown UI as associated with diseases such as: infection of the urinary $\operatorname{tract}^{11}$, arterial hypertension ${ }^{12}$, diabetes mellitus ${ }^{6,12-14}$, a history of cardiac disease ${ }^{4}$, obesity ${ }^{4,6,10}$, strokes $^{6,8,13,15}$, respiratory problems ${ }^{8,15}$, depression ${ }^{6}$, cognitive deficit ${ }^{16}$, arthritis ${ }^{12}$, arthrosis/rheumatism ${ }^{17}$, prostatic hyperplasia $^{18}$, a history of falls ${ }^{4,17}$, functional limitations, limited mobility or dependence $e^{6,8,11,14,16,18}$, comorbidity $^{19}$ and frailty ${ }^{17}$. in addition to these conditions, UI may be associated with lifestyle habits such as sedentiarism ${ }^{20}$. There is also an association with polypharmacy ${ }^{8}$, gynecological surgery, hysterectomies and the menopause in women ${ }^{20}$, a negative self-assessment of health status ${ }^{9,15,17}$ and poor quality of life ${ }^{19}$.

The importance of this theme is not only because of the high prevalence of UI among the elderly population in the country ${ }^{6,8,10,21}$, but due to its repercussions on physical, psychological and social aspects. UI tends to cause changes in the routine of the elderly, social isolation due to embarrassment and the loss of self-esteem, and impairments in quality of life ${ }^{2,22}$. In addition, embarrassment may prevent these individuals seeking professional help and diagnosis of the problem, making coexistence with this dysfunction permanent ${ }^{2}$. Although its symptoms are still underestimated or omitted due to the feeling of shame or because it is seen as part of the natural process of aging ${ }^{1,8,23}$, UI is considered a major complaint in health care.
There are few population-based epidemiological surveys for the study of UI in the Brazilian elderly population ${ }^{6,8,14,22}$, especially in relation to the magnitude of its relationship with other health indicators. Few studies have demonstrated the impact of UI on the physical and mental health conditions of the elderly population, reinforcing the importance of its use as a health marker for the investigation of other conditions, such as functional disability ${ }^{24,25}$, depression $^{26-28}$, the self-perception of poor/very poor health ${ }^{29,30}$ and cognitive deficit.

The aim of this study was to verify the prevalence of UI and its relationship with physical and mental health indicators in the elderly population living in the urban area of Bagé, Rio Grande do Sul, Brazil, in order to identify the magnitude of the problem and support the organization of care and health policies, mainly in the area of primary care.

\section{METHOD}

This cross-sectional population-based study was carried out between July and November 2008 with the elderly population living in the urban area of Bagé, located on the border of the state of Rio Grande do Sul (RS) and Uruguay. In the year of the study, approximately 122,461 inhabitants lived in this municipal region, of which 14,792 (12.0\%) were elderly. Of the total population, $82 \%$ lived in the urban area. The coverage of the family health strategy in the region was $54 \%$.

The sample size was calculated for a matric study that had as an outcome the "need for home care" and "receives home care"31. In this scenario, a sample of 1,530 individuals with a $95 \%$ confidence level was stipulated, and a statistical power of $80 \%$ was established to detect a relative risk of at least 1.5 for exposures affecting up to $4 \%$ of the population. For the calculation of the final sample, $10 \%$ for losses and refusals, $15 \%$ for confounding factors and a delineation effect of 1.3 were applied.

The criteria for inclusion were: individuals aged 60 years or older, living in private households, in the urban area of the municipal region of Bagé (RS), located in the areas covered by basic health care 
services. The sampling process was carried out in two stages based on the area covered by all 20 Basic Health Units (BHU), with 15 Family Health Units and five traditional BHUs. The area of the BHUs was divided into micro areas, with the numerical identification of each block, randomly selecting the initial point of data collection and each of the blocks by the drawing of lots. In order to ensure that all households had the same probability of inclusion in the sample, systematic skipping was used and one in every six residences was visited to locate the elderly. All residents aged 60 years or older residing in selected households were invited to participate in the study. Households where it was not possible to perform Interviews after three attempts on different days and times were considered losses, and those where the elderly did not agree to answer the questionnaire were considered refusals ${ }^{32}$.

Data collection was performed by duly trained interviewers using a questionnaire structured with pre-coded questions, answered by the elderly individuals themselves. In the case of disability, the questionnaire was applied to the caregiver.

The occurrence of "urinary incontinence" was investigated through the following questions: Do you have trouble with leaking some urine and accidentally wetting yourself?; In the last 30 days, how often did this happen?; In what situations do you leak urine? Because of the problem of leaking urine, do you use liners, absorbent pads, or diapers?. Using UI as a health marker, the following physical and mental health indicators were evaluated: Functional Disability for Activities of Daily Living (ADL) assessed by the Katz et al scale, screening for cognitive deficit assessed by the Mini Mental State Examination, depression evaluated by the Geriatric Depression Scale and Self-perception of Health ${ }^{1}$.

The independent variables used were the demographic and socioeconomic variables: gender (female and male), age in complete years (60 to 64 years, 65 to 69 years, 70 to 74 years, 75 years or more), self-described skin color (white, black, yellow/ / brown/indigenous), economic classification according to the Brazilian Association of Research Companies $(\mathrm{A} / \mathrm{B}, \mathrm{C}, \mathrm{D} / \mathrm{E})$ and schooling in full years (none, 1 to 7,8 or more).

Data analysis was performed using the statistical program Stata version 12.0 (Stata Corporation, College Station, USA). Qualitative variables were expressed as absolute and relative frequencies and the quantitative variables as means and standard deviation (SD), with a 95\% confidence interval (CI). Crude and adjusted analysis was performed using Poisson regression with robust variance adjustment to estimate the prevalence ratios (PRs) and their respective 95\% CIs. An adjustment was made for demographic and socioeconomic variables. Associations with $p$ value $<0.05$ were considered statistically significant.

The study was submitted to and approved by the Ethics Research Committee of the Universidade Federal de Pelotas under registration $n^{\circ} 15 / 08$, following the precepts of Resolution $n^{\circ} 196 / 1996$. The participants were informed about the research objectives and asked to read and sign a Free and Informed Consent Form.

\section{RESULTS}

A total of 1,593 elderly persons were interviewed, most of whom were female $(62.8 \%)$. The mean age was 71.2 years (95\% CI 63.0-79.4), ranging from 60 to 106 years, and the majority self-described their skin color as white $(81.7 \%)$. There was a higher proportion of elderly married persons or those with companions (51.3\%), and those who belonged to economic class C (38.9\%). Regarding schooling, 23.9\% reported not attending school and $54.5 \%$ had one to seven years of schooling. The majority of the elderly reported being retired $(71.7 \%)$ (Table 1$)$. 
Table 1. Sociodemographic characteristics of sample of elderly population. Bagé, Rio Grande do Sul, 2008.

\begin{tabular}{|c|c|}
\hline Variables & $\mathrm{n}(\%)$ \\
\hline \multicolumn{2}{|l|}{ Gender } \\
\hline Male & $593(37.2)$ \\
\hline Female & $1000(62.8)$ \\
\hline \multicolumn{2}{|l|}{ Age } \\
\hline 60 to 64 years & $400(25.1)$ \\
\hline 65 to 69 years & $374(23.5)$ \\
\hline 70 to 74 years & $322(20.2)$ \\
\hline 75 years or more & $497(31.2)$ \\
\hline \multicolumn{2}{|c|}{ Skin color/Ethnicity (self-reported) } \\
\hline White & $1252(78.6)$ \\
\hline Black & $139(8.7)$ \\
\hline Yellow, brown, indigenous & $202(12.7)$ \\
\hline \multicolumn{2}{|l|}{ Marital status* } \\
\hline Married or with companion & $816(51.3)$ \\
\hline Single or separated & $238(14.9)$ \\
\hline Widowed & $538(33.8)$ \\
\hline \multicolumn{2}{|c|}{ Economic classification - ABEP** } \\
\hline$A$ and $B$ & $429(27.1)$ \\
\hline $\mathrm{C}$ & $615(38.9)$ \\
\hline $\mathrm{D}$ and $\mathrm{E}$ & $537(34.0)$ \\
\hline \multicolumn{2}{|l|}{ Years of schooling* } \\
\hline None & $382(23.9)$ \\
\hline One to seven years & $868(54.5)$ \\
\hline Eight to 20 years & $342(21.6)$ \\
\hline \multicolumn{2}{|l|}{ Retired } \\
\hline No & $451(28.3)$ \\
\hline Yes & $1142(71.7)$ \\
\hline Total & $1593(100)$ \\
\hline
\end{tabular}

ABEP $=$ Brazilian Association of Research Companies. ${ }^{* 1}$ loss. $* * 12$ losses.

The prevalence of UI was $20.7 \%$. Of these, in the 30 days prior to the interview, $36.9 \%$ reported daily urine leakage, 39.4\% weekly leakage and 23.5\% monthly leakage. Among incontinent individuals, $33.4 \%$ reported using a diaper or liner, of which $20.9 \%$ used only when they left the house, $17.2 \%$ used only when sleeping and $61.8 \%$ used all the time.

The prevalence of UI was $26.9 \%$ among women and $10.3 \%$ among men $(p=<0.001)$. It was $28.4 \%$ in elderly persons aged 75 years or more $(p=<0.001)$; $27.9 \%$ among elderly people with yellow, brown or indigenous skin color $(p=0.031) ; 20.3 \%$ among economic class $\mathrm{D}$ and $\mathrm{E}(p=0.622)$; and $26.3 \%$ among those without schooling $(p=0.002)$, considering the total population (Table 2 ).
When verifying the prevalence of UI, stratified by gender, according to demographic and socioeconomic variables, it was possible to identify a significant increase in prevalence among women aged 75 years or older and those with yellow, brown or indigenous skin color. Among elderly men, the prevalence of UI was significantly higher in the age group of 70 to 74 and 75 years or older and among those with no schooling.

When assessing the relationship between UI and physical and mental health conditions, it was noted that, among the incontinent elderly population, there is a higher prevalence of functional disability, depression, cognitive deficit and a poor/very poor self-perception of health in both genders (Figure 1). 
Table 2. Prevalence of urinary incontinence in the elderly according to the demographic and socioeconomic variables in the total sample and stratified by gender. Bagé, Rio Grande do Sul, 2008.

\begin{tabular}{|c|c|c|c|c|c|c|}
\hline \multirow{3}{*}{ Variables } & \multicolumn{6}{|c|}{ Urinary Incontinence } \\
\hline & \multicolumn{2}{|r|}{ Total } & \multicolumn{2}{|r|}{ Women } & \multicolumn{2}{|r|}{ Men } \\
\hline & $\%$ & cPR* (CI95\%) & $\%$ & cPR* (CI95\%) & $\%$ & cPR* $(\mathrm{CI} 95 \%)$ \\
\hline Gender & & $p=<0.001$ & - & - & - & - \\
\hline Male & 10.3 & 1.00 & - & - & - & - \\
\hline Female & 26.9 & $2.61(2.02-3.28)$ & - & - & - & - \\
\hline Age & & $p=<0.001$ & & $p=<0.001$ & & $p=<0.001$ \\
\hline 60 to 64 years & 13.8 & 1.00 & 20.0 & 1.00 & 3.9 & 1.00 \\
\hline 65 to 69 years & 17.4 & $1.26(0.91-1.76)$ & 23.6 & $1.18(0.84-1.66)$ & 7.1 & $1.83(0.68-4.92)$ \\
\hline 70 to 74 years & 21.4 & $1.56(1.13-2.15)$ & 27.8 & $1.39(0.99-1.95)$ & 11.7 & $3.03(1.21-7.58)$ \\
\hline 75 years and over & 28.4 & $2.07(1.56-2.74)$ & 33.8 & $1.69(1.26-2.27)$ & 17.9 & $4.61(1.97-10.79)$ \\
\hline Skin color & & $p=0.031$ & & $p=0.011$ & & $p=0.779$ \\
\hline White & 20.0 & 1.00 & 25.7 & 1.00 & 10.2 & 1.00 \\
\hline Black & 17.3 & $0.86(0.59-1.27)$ & 21.1 & $0.82(0.54-1.24)$ & 10.2 & $1.01(0.42-2.41)$ \\
\hline Yellow or brown or indigenous & 27.9 & $1.40(1.09-1.79)$ & 38.8 & $1.51(1.17-1.94)$ & 11.3 & $1.11(0.57-2.17)$ \\
\hline Economic class & & $p=0.622$ & & $p=0.056$ & & $p=0.124$ \\
\hline$A$ and $B$ & 21.7 & 1.00 & 30.8 & 1.00 & 8.5 & 1.00 \\
\hline $\mathrm{C}$ & 20.5 & $0.95(0.74-1.20)$ & 27.1 & $0.88(0.69-1.12)$ & 8.9 & $1.05(0.55-1.99)$ \\
\hline $\mathrm{D}$ and $\mathrm{E}$ & 20.3 & $0.94(0.73-1.20)$ & 23.9 & $0.77(0.60-1.00)$ & 13.6 & $1.59(0.87-2.92)$ \\
\hline Schooling (years of study) & & $p=0.002$ & & $p=0.069$ & & $p=0.002$ \\
\hline Eight to 20 years & 17.0 & 1.00 & 24.4 & 1.00 & 4.6 & 1.00 \\
\hline One to seven years & 20.0 & $1.18(0.90-1.54)$ & 25.7 & $1.05(0.80-1.39)$ & 10.5 & $2.26(0.97-5.25)$ \\
\hline none & 26.3 & $1.55(1.16-2.08)$ & 32.0 & $1.31(0.97-1.77)$ & 16.0 & $3.45(1.44-8.27)$ \\
\hline
\end{tabular}

${ }^{*} \mathrm{cPR}=$ crude Prevalence Ratio

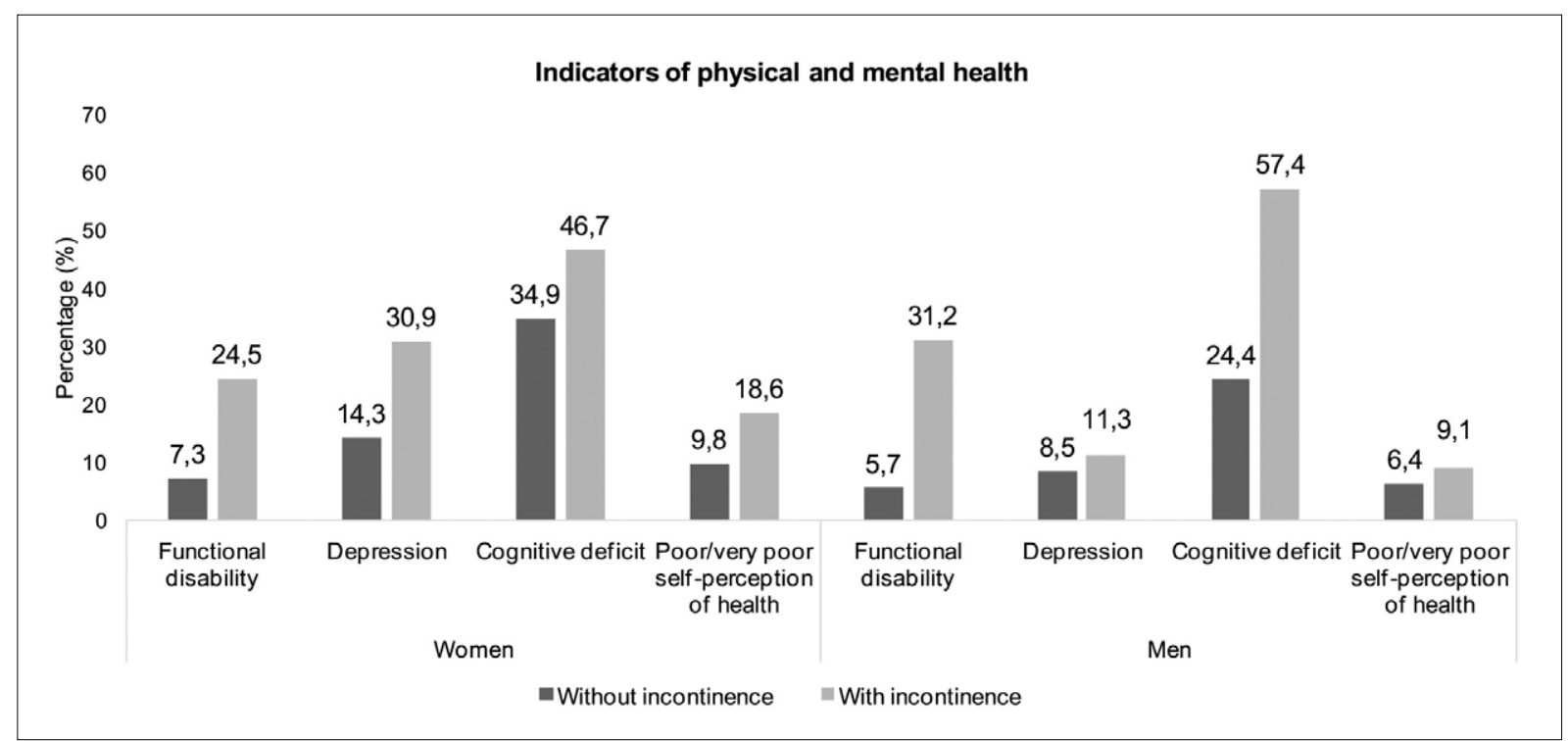

Figure 1. Proportional distribution of functional disability, depression, cognitive deficit and poor/very poor self-perception of health among the elderly with and without urinary incontinence, according to gender. Bagé, Rio Grande do Sul. 2008. 
In crude analysis, functional impairment for ADL and cognitive deficit were found to be associated with the presence of UI in the male and female population. Depression and poor/very poor self-perception of health were associated only with women (Table 3).

Table 3. Association of indicators of functional disability, depression, cognitive deficit and poor/very poor selfperception of health and urinary incontinence in the elderly population, according to gender. Bagé, Rio Grande do Sul, 2008.

\begin{tabular}{|c|c|c|c|c|}
\hline \multirow[t]{2}{*}{ Variables } & \multicolumn{4}{|c|}{ Urinary Incontinence ${ }^{\# \#}$} \\
\hline & cPR* (CI95\%) & $\mathrm{P}$ & $\operatorname{adjPR}{ }^{\#}(\mathrm{CI} 95 \%)$ & $\mathrm{p}$ \\
\hline \multicolumn{5}{|l|}{ Women (1000) } \\
\hline Functional disability $* *(1000)$ & $3.38(2.42 ; 4.72)$ & 0.000 & $2.79(2.03-3.85)$ & 0.000 \\
\hline Depression (951) & $2.16(1.67 ; 2.81)$ & 0.000 & $2.21(1.69 ; 2.89)$ & 0.000 \\
\hline Cognitive deficit (952) & $1.34(1.13 ; 1.58)$ & 0.001 & $1.18(1.02 ; 1.38)$ & 0.027 \\
\hline Poor/very poor self-perception of health (965) & $1.91(1.36 ; 2.69)$ & 0.000 & $1.86(1.31-2.65)$ & 0.001 \\
\hline \multicolumn{5}{|l|}{ Men (593) } \\
\hline Functional disability**(592) & $5.51(3.31 ; 9.18)$ & 0.000 & $4.45(2.60 ; 7.62)$ & 0.000 \\
\hline Depression (561) & $1.34(0.60 ; 3.00)$ & 0.480 & $1.22(0.53 ; 2.83)$ & 0.645 \\
\hline Cognitive deficit (562) & $2.35(1.78 ; 3.10)$ & 0.000 & $1.55(1.18 ; 2.05)$ & 0.002 \\
\hline Poor/very poor self- perception (575) & $1.43(0.58 ; 3.52)$ & 0.433 & $1.13(0.45 ; 2.88)$ & 0.794 \\
\hline
\end{tabular}

${ }^{*} \mathrm{cPR}=$ Crude Prevalence Ratio

\#adjPR = Prevalence Ratio adjusted for the variables: age, skin color, economic class and schooling.

**Functional disability for Activities of Daily Living (ADL)

\#\#Used as a reference for the category "no".

In the analysis adjusted for demographic and socioeconomic variables, the physical and mental health indicators remained associated with UI in both sexes. Women with UI had, respectively, 2.8, 2.2, 1.2 and 1.9 times the odds of having functional disability for ADL, depression, cognitive deficit and poor/very poor self-perception. Among males, functional disability and $\operatorname{cog}$ nitive deficit were 4.5 and 1.6 times greater, respectively, among those who had incontinence compared with those who did not.

\section{DISCUSSION}

The prevalence of UI reveals that the problem affects one in five elderly people in the municipality of Bagé (Rio Grande do Sul), with greater occurrence among women, those with advanced age, yellow, brown or indigenous skin color and those without schooling. Evaluating the health of the elderly population using the UI health marker, incontinent women showed a significantly higher prevalence of functional disability for ADL, depression, cognitive deficit and poor/very poor self-perception of health. Elderly men with UI had a higher prevalence of functional disability and cognitive deficit.

The findings on the general prevalence of UI corroborate the results of population-based studies conducted with elderly people in São Paulo (São Paulo) ${ }^{6}$ and in Florianópolis (Santa Catarina) ${ }^{8}$. However, research on the prevalence of UI has shown great variability $7,11,12,17,19,21,33$. This may occur due to sample choice, the age and gender of the population investigated ${ }^{33}$, the fact that prevalence is often higher among elderly persons in long-term institutions ${ }^{19}$; and the type of instrument used for UI assessment, whether self-reported or clinical diagnosis. This variability can also be explained by the adoption of different definitions for UI or even different methodologies ${ }^{6}$. It can also be attributed to cultural differences between regions in how UI is perceived by older adults ${ }^{18}$.

As for the frequency of urine loss, the prevalence of elderly people who reported suffering from this 
problem on a daily basis was higher than that observed in a study carried out with elderly women from a care center for the elderly in Pelotas (Rio Grande do Sul) $)^{21}$ and women aged 18 to 89 years who sought cervical cancer screening in Florianópolis $(\text { Santa Catarina) })^{9}$. The frequency and amount of urine leakage are due to several factors, such as: type of UI, elderly health status, comorbidities and degree of functional dependence ${ }^{11}$.

Regarding the factors associated with UI, women presented a higher prevalence $(26.9 \%)$ than men $(10.3 \%)$. The self-reported prevalence of UI by the elderly was $36.3 \%$ in women and $17.0 \%$ in men in a study carried out in Florianópolis (Santa Catarina) ${ }^{8}$, $26.2 \%$ in women and $11.8 \%$ in men in São Paulo (São Paulo) ${ }^{6}, 69.5 \%$ in women and 30.5\% in men in Uberaba (Minas Gerais) ${ }^{10}$, and $31.1 \%$ in women and $23.2 \%$ in men in Montes Claros (Minas Gerais) ${ }^{17}$. In a study in Korea with people 60 years of age or older, UI was reported in $6.5 \%$ of women ${ }^{15}$ and $3.9 \%$ of $\mathrm{men}^{18}$. And in the USA, in a study with women and men aged 50 years or older, the prevalence of UI was 19.8 and $6.4 \%$, respectively ${ }^{7}$.

In all surveys, the female gender appears to be the most affected and associated with UI, which may be related to the differences between the length of the urethra; the anatomy of the pelvic floor; the effects of gestation and giving birth on UI mechanisms; and hormonal changes ${ }^{6}$.

The tendency for the prevalence of UI to grow as the age of the elderly person increases has been identified by both Brazilian ${ }^{6,8,11}$ and non-Brazilian studies $^{7,12}$. Aging with increasing prevalence of comorbidities causes physiological changes. Thus, it is not surprising that advanced age is associated with the loss of bladder control, since urine control depends on a complex set of neurophysiological pathways, normal neuromuscular and connective tissue function, and adequate cognition and mobility?

In Bagé (Rio Grande do Sul), yellow, brown or indigenous skin color increased the occurrence of UI by $40 \%$ in relation to white elderly persons, corroborating the results of a study carried out in Florianópolis $(\mathrm{SC})^{9}$. According to literature, white women have better knowledge about UI than black women and more frequently undergo surgical treatment ${ }^{34}$. Another hypothesis is that white elderly persons may have better socioeconomic conditions, which favors seeking out preventive measures.

In contrast, a survey conducted in the USA showed that being non-Hispanic white increased the chance of UI in relation to other ethnic groups?. Thus, it is difficult to know whether the racial disparities observed are due to actual differences or if there are differences in the level of knowledge about the problem or in reporting urinary dysfunction among the various ethnic-racial groups, according to accepted cultural norms ${ }^{34}$.

In the present survey, the absence of schooling was related to a higher probability of UI. Similar results are found in literature ${ }^{8,10}$. Absence or low levels of schooling can make early detection and the seeking of treatment and preventive strategies difficult, as there may be a belief that UI is a natural consequence of the aging process ${ }^{1}$. In addition, healthcare professionals should use clear language that facilitates understanding in the socialization of information on the subject ${ }^{10}$.

After adjustment for demographic and socioeconomic variables, it was possible to identify a higher prevalence of functional disability, depression, cognitive deficit and poor/very poor self-perception of health among elderly individuals with UI. These results show the necessity and importance of the evaluation of physical and mental health indicators in the elderly that relate to UI.

The relationship between UI and functional capacity has been verified in non-Brazilian studies $^{24,25}$. Longitudinal research conducted in Norway has confirmed UI as a significant risk factor for decline in functional capacity among older women ${ }^{24}$. In a cohort study performed in the USA ${ }^{25}$, older women with daily UI had a greater chance $(\mathrm{OR}=3.31)$ of functional difficulty or dependence than those who were continent, after adjusting for sociodemographic variables.

This study does not involve longitudinal followup and these results are likely to be the fruits of reverse causality, as while it is difficult to say that UI causes functional disability, the opposite can be stated ${ }^{6,8,11,14,16,18}$. One study ${ }^{25}$ justifies this result 
by stating that incontinent women reduce physical activity due to fear of accidental urine loss and, consequently, there is an increase in functional limitations.

In relation to depression, there are several publications that show UI as a risk factor for the disease. A survey ${ }^{27}$ conducted with Norwegians showed that, after adjustments, women with UI had around a 1.60 greater chance of developing depressive disorder and anxiety compared to women without UI. Cross-sectional studies ${ }^{26,28}$ with women over 50 years of age in the USA showed an increase in the prevalence of depression as the frequency and severity of UI increased.

Incontinent women often avoid social activities and thus have smaller social networks, which, in turn, have an impact on mental health and contribute to the development of depression ${ }^{26}$. However, we cannot disregard depression as a risk factor for UI, which was verified in a national cohort study ${ }^{6}$.

The prevalence of cognitive deficit was significantly higher among those with incontinence than those who do not, in both genders, with a higher prevalence in incontinent men. While there is no evidence to show UI as a risk factor for cognitive deficit, this result makes clear the importance of assessing the condition in elderly individuals who report or have a diagnosis of UI. It is known that mental deficiency is an important risk factor for the development of incontinence ${ }^{16}$, despite the scarcity of studies.

The prevalence of a poor/very poor selfperception of health increased among incontinent women, with no significant association among men. This association is expected considering the impact of UI on the psychosocial life of the elderly. In a population study ${ }^{29}$ of elderly persons in Cuiabá (Mato Grosso) it was found that the self-assessment of poor and very poor health was 1.33 times higher among incontinent elderly than those who did not have UI. A study ${ }^{30}$ performed with elderly individuals 65 years of age or older in Belém (PA) $(\mathrm{n}=571)$ and in Campinas (SP) $(n=676)$, showed that in both cities negative self-assessment of health was associated with the presence of three or more signs and symptoms, including UI.
The association of depression and self-rated poor/ very poor health with UI among women may be related to the fact that this population group tends to expose their feelings and health problems more than men. In addition, women account for more than $60 \%$ of the population of this study, and there is therefore greater power to find associations. It is also worth noting that most of the studies conducted with the elderly focus on the female population, and there is a need to broaden this theme among elderly men.

Among the limitations of the present study, we highlight the fact that the association between the types of UI and the health conditions studied was not investigated. There is also the possibility that the individuals of the study were in drug treatment for $\mathrm{UI}$ and at the time of data collection did not mention urine leakage. In a cross-sectional study, it is not possible to assess the temporal relationship of UI with functional disability, depression, cognitive deficit and poor/very poor health self-perception. It is suggested that longitudinal surveys are carried out to verify the causal relationship between the variables. It is also worth mentioning that while there is no biological plausibility that UI causes functional disability and cognitive deficit, the relationship of these conditions with incontinence is evident, highlighting the need to evaluate physical and mental health conditions in the practice of care of the elderly with a diagnosis of UI. These are common conditions in primary care and negatively affect the quality of life of the elderly. These findings may support public policies for the elderly population, strategies to prevent UI and its effects on the health of this population and the organization of treatment in primary health care.

\section{CONCLUSION}

The results of this study reveal that urinary incontinence is a frequent condition among the elderly, affecting one in five individuals. In addition, its prevalence is higher among the elderly, women, older elderly people, those with yellow or brown skin or indigenous, and those without schooling. Incontinence was related to physical and mental health indicators, with a higher occurrence of functional disability, depression, cognitive deficit and a poor/very poor self-perception of health in incontinent elderly persons. 
Urinary incontinence should not be understood as a normal alteration of the physiology of aging, and thus health education actions and guidelines for individuals at all ages are required. In this sense, the training of health professionals regarding the approach to incontinence, methods of evaluation and early diagnosis, and knowledge about the risk factors is urgently needed. It is suggested that longitudinal studies are carried out to verify the relationship between incontinence and physical and mental health indicators, as well as the impact on the quality of life of the elderly.

\section{REFERENCES}

1. Ministério da Saúde. Envelhecimento e saúde da pessoa idosa. Brasília, DF: MS; 2007.

2. Honório MO, Santos SMA. Incontinência urinária e envelhecimento: impacto no cotidiano e na qualidade de vida. Rev Bras Enferm [Internet]. 2009 [acesso em 10 fev. 2017];62(1):51-6. Disponível em: http://www. scielo.br/pdf/reben/v62n1/08.pdf

3. Moraes EN, Marino MCA, Santos RR. Principais síndromes geriátricas. Rev méd Minas Gerais [Internet]. 2010 [acesso em 10 fev. 2017];20(1):5466. Disponível em: file://D:/Usuario/Downloads/ v20n1a08\%20(1).pdf

4. Bresee C, Dubina ED, Khan AA, Sevilla C, Grant $\mathrm{D}$, Eilber KS, et al. Prevalence and Correlates of Urinary Incontinence Among Older, CommunityDwelling Women. Female Pelvic Med Reconstr Surg [Internet]. 2014 [acesso em 10 fev. 2017];20(6):328-33. Disponível em: https:/www.ncbi.nlm.nih.gov/pmc/ articles/PMC5063232/pdf/nihms625935.pdf

5. Abrams P, Cardoso L, Fall M, Griffiths D, Rosier P, Ulmsten U, et al. The standardisation of terminology of lower urinary tract function: report from the standardisation sub-committee of the International Continence Society. Urology [Internet]. 2003 [acesso em 10 fev. 2017];61(1):37-49. Disponível em: http://www.goldjournal.net/article/ S0090-4295(02)02243-4/pdf

6. Tamanini JT, Lebrão ML, Duarte YA, Santos JL, Laurenti R. Analysis of the prevalence of and factors associated with urinary incontinence among elderly people in the Municipality of São Paulo, Brazil: SABE Study (Health, Wellbeing and Aging). Cad Saúde Pública [Internet]. 2009 [acesso em 10 fev. 10];25(8):1756-62. Disponível em: http://www.scielo. $\mathrm{br} / \mathrm{pdf} / \mathrm{csp} / \mathrm{v} 25 \mathrm{n} 8 / 11 . \mathrm{pdf}$

7. Wu JM, Matthews CA, Vaughan CP, Markland AD. Urinary, Fecal, and Dual Incontinence in Older U.S. Adults. J Am Geriatr Soc [Internet]. 2015 [acesso em 10 fev. 2017];63(5):947-53. Disponível em: https:// www.ncbi.nlm.nih.gov/pmc/articles/PMC4569486/ pdf/nihms692929.pdf
8. Marques LP, Schneider IJC, Giehl MWC, Antes DL, D’Orsi E. Demographic, health conditions, and lifestyle factors associated with urinary incontinence in elderly from Florianópolis, Santa Catarina, Brazil. Rev Bras Epidemiol [Internet]. 2015 [acesso em 10 fev. 2017];18(3):595-606. Disponível em: http:// www.scielo.br/pdf/rbepid/v18n3/1415-790Xrbepid-18-03-00595.pdf

9. Sacomori C, Negri NB, Cardoso FL. Incontinência urinária em mulheres que buscam exame preventivo de câncer de colo uterino: fatores sociodemográficos e comportamentais. Cad Saúde Pública [Internet]. 2013 [acesso em 10 fev. 2017];29(6):1251-9. Disponível em: http://www.scielo.br/pdf/csp/v29n6/a21v29n6.pdf

10. Bolina AF, Dias FA, Santos NMF, Tavares DMS. Self-reported urinary incontinence in elderly and its associated factors. Rev RENE [Internet]. 2013 [acesso em 10 fev. 2017];14(2):354-63. Disponível em: file://D:/ Usuario/Downloads/909-6279-1-PB\%20(1).pdf

11. Silva VA, Elboux MJ. Factors associated with urinary incontinence in elderly individuals who meet frailty criteria. Texto \& Contexto Enferm [Internet]. 2012 [acesso em 10 fev. 2017];21(2):338-47. Disponível em: http://www.scielo.br/pdf/tce/v21n2/en_a11v21n2.pdf

12. Asemota O, Eldemire-Shearer D, Waldron NK, Standard-Goldson A. Prevalence of Self-reported urinary incontinence in community-dwelling older adults of Westmoreland, Jamaica. MEDICC Rev [Internet]. 2016 [acesso em 10 fev. 2017];18(1-2):41-5. Disponível em: http://www.scielosp.org/pdf/medicc/ v18n1-2/1555-7960-medicc-18-01-02-0041.pdf

13. Santos CRS, Santos VLCG. Prevalence of urinary incontinence in a random sample of the urban population of Pouso Alegre, Minas Gerais, Brazil. Rev Latinoam Enferm [Internet]. 2010 [acesso em 10 fev. 2017];18(5):1-8. Disponível em: http://www. scielo.br/pdf/rlae/v18n5/10.pdf

14. Tamanini JTN, Pallone LV, Sartori MGF, Girão MJBC, dos Santos JLF, de Oliveira Duarte YA, et al. A populational-based survey on the prevalence, incidence, and risk factors of urinary incontinence in older adults-results from the "SABE STUDY". Neurourol Urodyn. 2017;9999:1-12. 
15. Park J, Hong GR, Yang W. Factors associated with self-reported and medically diagnosed urinary incontinence among communitydwelling older women In Korea. Int Neurourol J [Internet]. 2015 [ acesso em 10 fev. 2017];19(2):99-106. Disponível em: https://www.ncbi.nlm.nih.gov/pmc/articles/ PMC4490321/pdf/inj-19-2-99.pdf

16. Schumpf LF, Theil N, Scheiner DA, Fink D, Riese F, Betschart C. Urinary incontinence and its association with functional physical and cognitive health among female nursing home residents in Switzerland. BMC Geriatrics [Internet]. 2017 [acesso em 24 jan. 2018];17:1-17. Disponível em: https:// www.ncbi.nlm.nih.gov/pmc/articles/PMC5237224/ pdf/12877_2017_Article_414.pdf

17. Carneiro JA, Ramos JCF, Barbosa ATF, Medeiros SM, Lima CA, Costa FM, et al. Prevalência e fatores associados à incontinência urinária em idosos não institucionalizados. Cad Saúde Colet [Internet]. 2017 [acesso em 24 jan. 2018;25(3):268-77. Disponível em: http://www.scielo.br/pdf/cadsc/v25n3/1414-462Xcadsc-1414-462X201700030295.pdf

18. Park J, Hong GRS. Association of functional ability and benign prostatic hyperplasia with urinary incontinence in older Korean men. Int Neurourol J [Internet]. 2016 [acesso em 10 fev. 2017];20(2):137-42. Disponível em: https://www.ncbi.nlm.nih.gov/pmc/ articles/PMC4932637/pdf/inj-1630432-216.pdf

19. Silay K, Akinci S, Ulas A, Yalcin A, Silay YS, Akinci $\mathrm{MB}$, et al. Occult urinary incontinence in elderly women and its association with geriatric condition. Eur Rev Med Pharmacol Sci [Internet]. 2016 [acesso em 10 fev. 2017];20(3):447-51. Disponível em: http://www.europeanreview.org/wp/wp-content/ uploads/447-451.pdf

20. Silva JCP, Soler ZASG, Wysocki AD. Associated factors to urinary incontinence in women undergoing urodynamic testing. Rev Esc Enferm USP [Internet]. 2017[acesso em 24 jan. 2018];51:1-9. Disponível em: http://www.scielo.br/pdf/reeusp/v51/1980-220Xreeusp-51-e03209.pdf

21. Carvalho MP, Andrade FP, Peres W, Martinelli T, Simch F, Orcy RB, et al. O impacto da incontinência urinária e seus fatores associados em Idosas. Rev Bras Geriatr Gerontol [Internet]. 2014 [acesso em 10 fev. 2017];17(4):721-30. Disponível em: http://www.scielo. br/pdf/rbgg/v17n4/1809-9823-rbgg-17-04-00721.pdf
22. Tamanini JT, Santos JLF, Lebrão ML, Duarte YAO, Laurenti R. Association between urinary incontinence in elderly patients and caregiver burden in the city of Sao Paulo/ Brazil: Health, Wellbeing, and Ageing Study. Neurourol Urodyn [Internet]. 2011 [acesso em 10 fev. 2017];30(7):1281-85. Disponível em: https:// www.ncbi.nlm.nih.gov/pubmed/21560151

23. Tomasi AVR, Santos SMA, Honório GJS, Locks $\mathrm{MOH}$. Incontinência urinária em idosas: práticas assistenciais e proposta de cuidado âmbito da atenção primária de saúde. Texto \& contexto enferm [Internet]. 2017 [acesso em 15 maio 2017];26(2):1-10. Disponível em: http://dx.doi.org/10.1590/010407072017006800015

24. Omli R, Hunskaar S, Mykletun A, Romild U, Kuhry E. Urinary incontinence and risk of functional decline in older women: data from the Norwegian HUNTstudy. BMC Geriatr. 2013:1-6.

25. Erekson EA, Ciarleglio MM, Hanissian PD, Strohbehn K, Bynum JP, Fried TR. Functional disability and compromised mobility among older women with urinary incontinence. Female Pelvic Med Reconstr Surg. 2015;21(3):170-5.

26. Nygaard I, Turvey C, Burns TL, Crischilles E, Wallace R. Urinary incontinence and depression in middle-aged United States women. Obstet Gynecol. 2003;101(1):149-56.

27. Felde G, Bjelland I, Hunskaar S. Anxiety and depression associated with incontinence in middleaged women: a large Norwegian cross-sectional study. Int Urogynecol J. 2012;23(3):299-306.

28. Townsend MK, Minassian VA, Okereke OI, Resnick NM, Grodstein F. Urinary incontinence and prevalence of high depressive symptoms in black and white older women. Int Urogynecol J [Internet]. 2014 [acesso em 10 fev. 2017];25(6):823-9. Disponível em: https://www.ncbi.nlm.nih.gov/pmc/articles/ PMC4035387/pdf/nihms-548182.pdf

29. Cardoso JDC, Azevedo RCS, Reiners AAO, Louzada CV, Espinosa MM. Poor self-rated health and associated factors among elderly urban residents. Rev Gaúch Enferm. 2014;35(4):35-41.

30. Mantovani EP, de Lucca SR, Neri AL. Negative selfrated health in the elderly in cities with different levels of economic well-being: data from FIBRA. Ciênc Saúde Colet. 2015;20(12):3653-68. 
31. Thumé E, Facchini LA, Wyshak G, Campbell P. The Utilization of home care by the elderly in Brazil's Primary Health Care System. Am J Public Health [Internet]. 2011[acesso em 10 fev. 2017];101(5):868-74. Disponível em: https://www.ncbi.nlm.nih.gov/pmc/ articles/PMC3076415/pdf/868.pdf

32. Thumé E, Facchini LA, Tomasi E, Vieira LAS. Home health care for the elderly: associated factors and characteristics of access and health care. Rev Saúde Pública 2010;44(6):1102-111.

Received: January 29, 2018

Reviewed: May 08, 2018

Accepted: July 06, 2018
33. Silva AI, Almeida C, Aguiar H, Neves M, Teles MJ. Prevalência e impacto da incontinência urinária na qualidade de vida da mulher. Rev Port Med Geral Fam [Internet]. 2013 [acesso em 10 fev. 2017];29(6):364-76. Disponível em: http://www.scielo. mec.pt/pdf/rpmgf/v29n6/v29n6a04.pdf

34. Leroy LS, Lopes MHBM, Shimo AKK. Urinary incontinence in women and racial aspects: a literature review. Texto \& Contexto Enferm [Internet]. 2012 [acesso em 10 fev. 2017];21(3):692-701. Disponível em: http://www.scielo.br/pdf/tce/v21n3/en_v21n3a26.pdf 